\title{
From Endangered Family Towards own Family - Experiences and Expectations of Social Orphans
}

\author{
Anita Mencel
}

University of Wroclaw, Department of Historical and Pedagogical Sciences, Institute of Pedagogy, ul. J. W. Dawida 1, 50-527 Wrocław, Poland, mencel.a@wp.pl

\begin{abstract}
In the contemporary world family still constitutes a superior value, but on the other hand, is subject to influences of many destabilising factors that may disturb its appropriate functioning. "A child gets to know the world, own self, the others and life objectives directly experiencing such aspects of life within own family, as a family brings up through the presence of its members remaining with each other in a relation of love and kindness" (Kukułowicz, 2004). One of the basic functions of the family is socialisation that means "transmitting knowledge regarding the surrounding world, cultural heritage and preparation to fulfill adult social roles addressed to the offspring. The primary socialisation takes place within the family circle, where $<\ldots>$ an individual becomes a member of the society by internalisation and generalisation of the most overall meanings thanks to the mediation of those taking care of such individual" (Kawula, 2007). The children brought up in an orphanage are subject to a specific socialisation, located in the borderland of the functioning in an institution and the family of origin. The process of becoming independent reflects such type of socialisation.
\end{abstract}

Keywords: socialisation in the borderland, endangered family, social orphanage, institutional upbringing, the process of becoming independent among orphanage residents.

\section{Introduction}

The process of socialisation in a family begins from the earliest moments of the child's life and embraces such elements as the ability to communicate, acquiring experiences in 
encountering the material world (with particular attention drawn to the appliances of everyday life, living conditions and the material situation of a family), relations between given members of the family, getting to know the cultural values of the family, its moral advancement, life goals and points of views, as well as attitudes to work, learning, life duties, other people and their needs. Adopting individuals to fulfill social roles is one of the outcomes of such influences, including professional roles and those related to participation in given social groups. The meaning of socialisation understood in such way is to imitate the behaviour of the nearest surrounding, interiorisation of given system of principles and values accepted in a family and wider social circles, as well as social control which affirms desired conduct and represses the unwelcome behaviour (Adamski, 2002).

In the course of everyday life each family experiences problems that must be overcome, and in a family system that is significantly affected by negative factors, the development of children and teenagers brought up in such surrounding might be threatened. As a result, it may lead to the phenomenon of social orphanage that is one of the key causes of family life disturbances. It is a phenomenon bothersome for contemporary societies due to its wide range, various forms, difficulties of diagnoses and prevention of situations that generate such condition (Badora, 2002). There may be many reasons for such phenomenon to occur, therefore in the literature they are divided into macro- and micro social determinants. The first group, for instance, embraces unemployment, material insufficiency, homelessness, anonymity of life and change in the hierarchy of values and lifestyle, whereas the latter determinant refers to the family issues such as chronic diseases, lack of sufficient child's care, alcoholism, drug addiction, prostitution and number of unfulfilled children's needs (Węgierski, 2006).

Families that can face the difficulties and solve own problems successfully, strengthening own community and accomplishing assigned tasks at the same time, are referred to as functional. Such type of families looks after children and their needs, and as they grow old, teach them to fulfill own needs independently. In contrast dysfunctional families are not able to fulfill own functions sufficiently enough, hence parents, instead of protecting and supporting children, ignore them or even in some cases attack. In consequence, children develop dysfunctional features of self-preservation, i.e. adapt and rearrange own mental world in the way to avoid destructive sense of own worthlessness and shame of being humiliated. If they grow up in such circumstances, the probability of becoming dysfunctional parents in the future is very high (Kawula, 2007).

Researchers of the orphanage issues stress that depriving children of family care at early stage of life is a serious threat to their proper growth. Children rejected by parents feel unloved, not understood, lonely, unneeded and pushed off to the margin of a family life. They hardly know own parents and other relatives, thus, they have no one that could become a moral and emotional support to them. Consequently such situation affects social and moral attitude of such a young person (Badora, 2002). This, in turn, can lead to serious, negative consequences in the future. Still, it must be remembered that the 
repercussions resulting from social orphanage depend on many factors, among which the most important ones include: the child's age where the process of becoming an orphan begins, mental traumas, course of the process of family disintegration, quality of relations within a family and upbringing value of the new environment where a child is placed after separation from the biological family (Węgierski, 2006). If a child is deprived of appropriate parental care, he / she will be placed in a caretaking institution, where the new caretakers will introduce him / her to a new, positive code of conduct. Nonetheless, this, what such children have experienced in a family home will significantly influence their further biographies, however it will depend entirely on them how to live their own lives at the stage of adulthood.

\section{The process of becoming independent among orphanage residents}

The process of becoming independent is one of the key, if not most crucial, tasks that must be accomplished within framework of the socialisation institution priorities. It is a long-lasting process as it starts at the moment of taking care of the child by the institution and lasts after reaching the stage of formal independence of such person (Bieńko, 2006). Children brought up in socialisation institutions that leave such unit and begin their adult life must have foundation and a background that will allow them to function independently in a social, professional and most of all - family lifeat the monent ot most crucial taks that must be accomlished d emotional support to the (Stojecka-Zuber, 2009).

The institution must provide them with opportunities to experience such situations and activities which would enable them to fulfill various social roles successfully.

The upbringing agenda preparing the youth to independent life embraces the below-listed spheres.

Family life: appropriate functioning of those in orphanages is hindered, as preparing a child to an adult life within family takes place in stages, different forms and by participation in various situations, whereas the paradox of such institution is that lacking natural possibilities to enter family roles, it must prepare children to this aspect of life (Gajewska, 1997).

Everyday life functioning: related to the ability of self-service within organising family life and running a household (sharing duties and rights, ways of spending free time, managing home budget, handling official issues, paying bills, etc), and acquiring practical skills within running the household (e.g. knowledge how to prepare meals, which products to buy, how to serve the food aesthetically and consume it with manner), as well as shaping and instilling the habits of cultural life (Gajewska, 1997).

Functioning at school: providing appropriate accomplishment of school career with the objective to graduate school that would equip them with qualifications to work in 
chosen profession (Kamińska, 2004). Hence, it is emphasised, that "the essential task of a child in such institution is to learn and gain knowledge that enhances and strengthens the future life of the orphans. Systematic control of the preparation for the classes, checking attendance and taking responsibility for the absence from school teaches children to be held accountable for own issues (Kamińska, 2004).

Professional functioning: making children aware of the value of work is a difficult task, as being brought up in an environment where everything is common and shared, and many things are given because they have the right to receive them, makes it troublesome to shape the respect to work and positive attitude to this sphere of life (Broża, 2009). Therefore, it is important to make children aware that there is direct correlation between learning, i.e. educational background and the future professional career (Gajewska, 1997).

Social functioning: those in socialisation institutions manifests problems with interpersonal relations (do not trust others, have low self-esteem, feel lonely) what consequently involves the need to prepare them to deal with emotions, shape responsibility and resistance to stress, learn independent problem solving and maintaining positive social relations (Gajewska, 1997).

All the mentioned areas are tightly linked to each other and constitute the entirety of young people's functioning in their grown-up, independent life. However, the practice shows that "the youth leaving orphanage are underprepared to begin an adult life. They cannot establish a well-functioning family, undertake professional activity and experience problems with striking up relationship with other people" (Stojecka-Zuber, 2009).

It results from number of reasons as the process of becoming independent takes place individually and is not as much institutional as personal, depending on individual features and life position. The chosen tutor that supports the young in their pursuit of independence is of key importance. It can be the head of such institution, a caretaker, social worker of a given unit or local family support centre, or any other person appointed by a young person (Stojecka-Zuber, 2009). Such tutor's duty is to help in reaching the stage of independency which would enable young people to function in a grown-up life autonomously, i.e. with neither financial nor social care support, motivating them towards accomplishment of adopted goals. Such tutor is also obliged to complete the agenda of independency plan, however not doing it for the young persons, but helping them, assisting, talking things over and providing with advice, if asked. Such person is also obliged to intervene, if it is justified and necessary (Kwak, 2006).

Changes in the law regulating social support focus on the family of origin of such children, and in the context of the new approach it is referred to as "pro-family system of social care". Its premise is to work within dually understood re-integration, i.e. the family with the child and the child with the family, with its essential element of sustaining emotional bonds between the child and the family. It should start as early as possible with the mutual cooperation of both sides involved. However, in reality, accomplishing this task is extremely difficult as children often come from families that struggle with various 
problems and are unwilling to cooperate. Nonetheless, sometimes thanks to undertaken activities and cooperation between many subjects it is feasible to help given family in solving some vital problems and as a result, a child is able to return to the biological family. Such process is the superior goal of all caretaking efforts, nonetheless cooperation between the institution and a given family varies and is significantly influenced by the features of the family and its willingness to undertake the effort. Still, attempts are always maintained as it is impossible to begin work with children separately from their family of origin (Kwak, 2006).

The course of the process of becoming independent usually consists of two stages, with the first one embracing individuals and team work with those 15 - and 16 years old. Classes tackle plans referring to future life of the youth, emphasising their opportunities and providing information indispensible while looking for a job. The tutors teach and prepare children to acquire skills useful in handling a household, i.e. managing home budget, planning and doing shopping, dealing with various issues in public institutions, preparing meals, etc. Moreover, the attention is drawn to working out responsible attitude (indispensible in independent life), and skills of adequate assessment of own possibilities and surrounding reality, simultaneously acquiring and improving the ability to solve problems and communicate appropriately with others. The second stage prepares to active search for a job by the 17-year-old teenagers, including discussions, analysing the job market, informing about possibilities to have a flat allocated, and supporting in dealing with various kinds of official issues (Kwak, 2006).

Establishing conditions in orphanages to acquire practical skills is relatively accessible, however preparing to become independent within emotional sphere is always a complex, problematic task. It often happens that a young person leaves traditional orphanage not being able to set up appropriately functioning family, nor to undertake professional activity, additionally experiencing problems with interpersonal relations. For such young people it is difficult to find a job and a flat, be persistent in continuing further education and professional growth, as well as in minimising the level of anxiety related to the sense of independency. Moreover, it is a difficult task to engage the biological family of origin even to a small extent, as it arises problems with finding a place where such young person could return to, as they often have no place to go. Besides, sometimes the contact with such family is limited, if not absent at all (Stojecka-Zuber, 2009).

The situation of those being brought up in socialisation institution is complex and difficult in many ways. Referring to the circumstances of those living in such units, they may be defined as "torn between a family that has let them down many times and the institution they owe such much, but cannot find their own place in life afterwards. Being fully aware that their relatives are unable to provide them with appropriate care, they still keep hope that one day something will change. Grateful to their tutors for their help, they know after all it is only their professional duty that will never replace parental affection. All these factors make them feel worse than their counterparts from functional families 
and this feeling prevails in all spheres of life. Thus, they choose easier (less demanding) educational paths as they do not believe they can achieve more and they see themselves on a lower rank posts as they are convinced this is the best they can do. They take a certain distance to people as they fear getting hurt by others, approaching vision of own family life with similar anxiety, thinking they will not be able to handle the obligations and commitment. Their life dreams are also limited due to the painful awareness that so many dreams have remained unfulfilled. All these worries and anxiety are also reflected with regards to the idea of independency". $<\ldots$..> Those living in socialisation institutions (particularly orphanages) are fulfilled with objections, what is quite understood taking into consideration the fact that they are to function in a totally unknown surrounding, as life in such institutions is different from life beyond it. In such unit they get their clothes from the warehouse, meals are prepared by the cooks and most of the decisions take place out of their aware participation. They do not even know how much the simplest goods cost, whereas paying a bill becomes a real challenge. And all of a sudden, it turns out that all the issues that were taken care of by the tutors must be dealt with, and taken responsible for, individually. Hence, it is obvious that such radical changes generate all kinds of fears especially that after leaving such institution the young often remain all alone“ (Przygoda, 1998).

Summarising the above reflections it must be remembered that the process of becoming independent is complex and influenced by many factors, nonetheless the final goal of all undertaken activities is to equip a young person subject to such process with knowledge and skills to make them cope with the life reality. If such a person shall be able to accomplish it, it will prove such process to be successful, locating such young individual in the borderland of the family of origin and own family, being able to face challenges that a grown-up life involves.

\section{The process of becoming independent among orphanage residents as reflected in own research}

The below reflections refer to the results of my own research. Knowledge and experience that the respondents (becoming independent within such institutions) shared with me, provided number of crucial information within the researched area, as they highlighted the complexity of factors contributing to the course of such process. Still, despite the framework within given legal regulations, each case is different and individual. 


\section{The course of the process of becoming independent among children from socialisation institutions reflected in their narratives}

All the researched respondents were able to define what features are typical for independent person, claiming it is someone responsible for own actions making autonomic decisions, someone who can find a job and set up own family, is ready to live own life, overcome difficulties and can deal with many issues without assistance of other people. All respondents experienced the process of becoming independent in orphanages. Majority of them mark its beginning more less a year and a half before leaving the institution (from the moment of working out individual plan of becoming independent, choosing the tutor of this process and submitting applications to the local authorities to have a council flat allocated). They remember well what they have accomplished within the plan of becoming independent, i.e. they have determined the further steps after leaving the institutions in terms of finding a flat (how they were going to apply for it and the expected results), job (if they want to search for one, or if they already work - will they have to, or want to, change the place of work), and education (if to continue or plan to continue further education). They also consider preparation to complete everyday's tasks (such as laundry, cooking and cleaning), as well as the art of managing money as a part of this process. Only one of the respondents pointed that the process of becoming independent had started few years earlier, namely when he was 13 years old at the time when his caretakers began to teach him how to cope with everyday duties and life economically.

Therefore, none of the researched respondents perceive the process of becoming independent as M. Bieńko, who claims that it begins at the very moment of entering the institution (Bieńko, 2006). Only one the respondents considered introducing to the process of carrying out daily tasks as activity in favour of the process of becoming independent. As late as at the final stage of their stay in such institution, when it is formally a period referred to as "becoming independent", the caretakers launched activities directed towards the teenagers departure from the unit. The researched have also mixed feelings whether their process of becoming independent is completed or still taking place, as some claim it stopped when they left the institution and can count only on themselves, whereas others think it is being continued, as in many cases they ask their former tutors and caretakers for advice and accept their assistance.

The respondents are young, they are still learning and have vocational practices, in most cases their housing situation is not settled, hence support from their caretakers is indispensible and crucial as they claim themselves to have a lot to be overcome before they shall be able to refer to own selves as independent. Their feelings about the process of becoming independent are significantly related to the institution they were part of, whether they have experienced kindness from the caretakers and established positive emotional relations with them, whether they can count on their support despite not living 
in a given institution anymore, and whether there is anyone interested in their further course of life. The independently living former orphanage residents are the creators of the independency process to a different degree, as some claim it to be a fully aware stage, actively participated, with own plans, projects and accomplishment, dealing with official issues alone or with a slight support from the caretakers but still remaining autonomous, whereas others think many issues were settled for them and some processes took place beyond their control. Moreover, few claim there was not a lot of talking about this new stage of life they were about to enter. Nonetheless, it must be emphasised that none of the respondents experienced a situation to be left without any support or assistance after leaving such institution.

\section{The issue and expectations of the orphans towards becoming independent}

Expectations of those becoming independent in terms of the course of this process and its results vary significantly. Some count on themselves, not waiting for others to offer help, trying to deal with life independently and create the reality around them best way they can. Others rely on help and assistance, for instance in dealing with official issues or accepting advice when needed. All respondents appreciate help from those supporting them in becoming independent. Some say that even without such assistance they would handle with taking this step in life. Others find it an indispensible and necessary element without which they cannot imagine their preparation for independency. The issue who is responsible for the course of this process and its results is also perceived from various angles. Most of the respondents think they are responsible for this stage, however there are also some who claim that the tutors are in charge and should do all they can to help the young people in this transition. There is also a group of those who claim that both the youth and the tutors are responsible for the course and result of this process and should do all they can to make it successful.

Taking it all into account it must be emphasised that all the respondents realise the importance and significance of this process. Most of them were or still are receiving support from the institution and none claimed that the tasks and activities undertaken in orphanage were unnecessary or useless. It seems that the awareness that they have persons they can turn to in difficult times allow the respondents to experience sense of security, as despite the fact that they are trying to deal with the reality independently, they are conscious that there is always somebody they can count on in the hour of need or doubt, being sure they will be listened and helped out, no matter if it concerns employees of this institution, family members, friends or other close persons. 


\section{Environmental context of becoming independent among the orphans}

The process of becoming independent among those living in socialisation institutions is a complex one, as it involves various institutions and persons from close or further social circle of persons becoming independent. The obligation of such institutions is to accomplish number of tasks which aim is to enable the young person to enter the adult stage of life.

The regional family support centre is the first institution the researched recall, as it secures the financial side of this process, arranging various courses, providing money for further education and etc. It must be emphasised that all those becoming independent have received assistance from this unit. Another institution cooperating with orphanages with this regard is the city council, as almost all of the respondents submitted applications to the mayors to have a council flat allocated, and as a result they have already received it, or are still waiting. The local councils in small towns also provide assistance, hence some of the respondents searched for support there too. They can also count on friends' and family's help. Moreover, one of the studies indicated school as a place she accepted support from. The young people also recall working community and place of their apprenticeship where they can earn some money. Essentially all of the respondents claim to have someone in their surrounding they can turn to when facing difficulties. It can be a tutor, a caretaker, a boyfriend or a girlfriend, or an employee of a regional family support centre.

The respondents are aware how many institutions are engaged in their process of becoming independent, then know where to search for assistance in emergency and have someone in their surrounding they can rely on when a piece of advice or emotional support is needed.

\section{The spheres of becoming independent with its implications from the perspective of researched orphans}

The spheres of respondents' life define their categories of the process of becoming independent, including family and everyday life, social life and school, as well as professional functioning. Each individual should - prior to leaving the institution - acquire appropriate skills and abilities in order to be able to function within these spheres without any serious difficulties. All the respondents deal relatively sufficient with the everyday tasks - they can do the cleaning, cook, do the washing and organise the shopping, and whether they enjoy it or not, they claim the caretakers have prepared them well to carry out these tasks. Moreover, the researched are aware of issues such as paying bills each month and manage the home budget well enough to have resources for essential 
expenses. Some of them still live in a hostel, what means not having to pay the bills and fees for the stay, besides, money they receive from apprenticeship or regional centres for family support is sufficient to cover their expenses related to buying food, clothes and other things. Others do not have a permanent job, but perform some odd jobs and receive money from for instance) regional centres to continue education. They all think it is essential not to get indebted. The life situation of the respondents in terms of their work and education is individual, however all posses their trained profession that can help to find a job if they want, or if their difficult financial situation shall make them do so. They also maintain interpersonal relationships of different quality - sometimes very close ones, sometimes keeping others at distance. As far as family life is concerned, some of them maintain contact with the sibling or parents, whereas some cut off from them entirely. None of the respondents plans to set up own family, however, apart from everyday functioning, they speak of their plans for the nearest future that is relatively defined, namely - some want to go abroad to find better job, whereas for others finding a job or continue education in Poland is the top priority.

The researched persons also notice various aspects of individual life, underlining its positive sides such as freedom and lack of other's surveillance (including being held responsible for own actions), not being dependent on others, being able to do what they wish, manifesting resourcefulness and ability to find a way out in each situation, as well as being accustomed to independency earlier than other peers. On the other hand, lack of someone who can listen to them and give some piece of advice, the fact of being forced by the circumstances to remember about many issues, taking care of own self (also financially), as well as lack of knowledge on how to begin autonomous life are altogether considered by them as some of the serious drawbacks of such step.

Difficulties while becoming independent as well as deficiencies during such process experienced by the respondents tackle many aspects, including changing the place of professional apprenticeship, difficult living conditions, or lack of practical advice (for instance how to behave during a job interview). On the other hand, they notice some issues as crucial in life, stressing the necessity to: have goals and dreams in life, experience support and respect from others, own a house or a flat, have a sense of harmony and concord, feel loved, have a job and a family, graduate a good school, and last but not least - not to give up while facing life difficulties.

Those researched deal with various aspects of life the best they can, what means in a manner they have been prepared to during the process of becoming independent. The respondents prove that the socialisation institutions undertake the effort to prepare them for the independency within all spheres, including family, everyday life, school, professional and social aspects. It is also important that while approaching difficulties, they know who to turn to for assistance, nonetheless sometimes being able to handle with the challenges on their own. They also know what matters in life most, and try to accomplish the goals they have set. 


\section{Conclusion}

The process of becoming independent in socialisation institution is accomplished in socialisation institutions with various results, depending on the attitudes of youth becoming independent, the personal features of the recipients and creators of such process, engagement of those in charge of the course of this process (the caretakers and etc), as well as depending on the level of accomplishing assigned tasks by the institutions obliged to provide assistance to those beginning independent life.

Majority of those becoming independent want to life different than their biological parents, as they want to love, work, set up families and achieve something in their lives. They have plans for the future, hence it would be a mistake to deprive them of the chance for better future. Nonetheless, solutions that would enable accomplishing the complexity of the tasks of new social care system are necessary (Czajka, 2004). Young people leaving socialisation institutions must be made aware that they can truly be in control of, and shape own lives, and if they try and make the effort, they can have normal lives as others, despite negative experiences from their childhood (Broża, 2009).

Specific type of socialization in a borderland of functioning in an institution and the family of origin reflected in the process of becoming independent and further adult life is both a chance and a challenge for such young people. The way they deal with it largely depends on them, hoverer prior experience and environmental context must be also taken into account. Individuals prepared to live independently, positively functioning in own adult life should set an example of the results of undertaken tasks, however it is notable influenced by those who shape their independency, their willingness and possibilities to acquire skills, gain education and the need to change own self.

\section{References}

Adamski, F. (2002). Rodzina. Wymiars połeczno-kulturowy (p. 40). Kraków: Wydawnictwo Uniwersytetu Jagiellońskiego.

Badora, S. (2002).Teoretyczne aspekty sieroctwaijego opiekuńczej kompensacji. In S. Badora, \&

D. Marzec (Eds.). System opieki kompensacyjnej w zjednoczonej Europie (pp. 51, 70). Kraków: Impuls.

Bieńko, M. (2006). Proces usamodzielnienia wychowanków domówdziecka, częśćdruga. Problemy Opiekuńczo-Wychowawcze, 5, 21.

Broża, P. (2009). Były wychowanek domu dziecka, oskarżenie czywyrok? Problemy OpiekuńczoWychowawcze, 4, 42, 44.

Czajka, B. (2004). Problemy usamodzielnia nowych wychowanków. Problemy OpiekuńczoWychowawcze, 7, 51. 
Gajewska, G. (1997). Przygotowanie wychowanków do samodzielnego życia i pełnienia pierwszoplanowych ról społecznych. In Z. Dąbrowski (Ed.). Węzłowe problemy opieki i wychowania w domudziecka (pp. 357-358, 360, 363, 367). Olsztyn: Wyższa Szkoła Pedagogiczna. Kamińska, U. (2004). Zarys metodyki pracy opiekuńczo-wychowawczej w rodzinnych i instytucjonalnych formach wychowania (pp. 92, 99-100). Katowice: Wydawnictwo UŚ.

Kawula, S., \& Janke, A. W. (2007). Polimorficzność i komplementarność badań nad współczesną rodziną. In S. Kawula, J. Brągiel, \& A. W. Janke (Eds.). Pedagogika rodziny. Obszaryi panorama problematyki (p. 40). Toruń: Adam Marszałek.

Kawula, S. (2007). Rodzina o skumulowanych czynnikach patogennych. In S. Kawula, \& J. Brągiel, A. W. Janke (Eds.). Pedagogika rodziny. Obszaryi panorama problematyki (pp. 148-151). Toruń: Adam Marszałek.

Kukołowicz, T. (2004). Rodzina w procesiewychowania. In A. W. Janke (Ed.). Pedagogika rodziny na progu XXI wieku (pp. 45-46). Toruń: Wydawnictwo Edukacyjne “AKAPIT".

Kwak, A. (2006). Kreatorzy procesu usamodzielnienia. In A. Kwak (Ed.). Z opiekizastępczej w dorosłeżycie. Założenia a rzeczywistość (pp. 88-90, 92-94, 131). Warszawa: Fundacja Instytutu Spraw Publicznych.

Przygoda, J. (1998). Biografiei start życiowy usamodzielnianych wychowanków różnych form opieki. In M. Kolankiewicz (Ed.). Zagrożone dzieciństwo. Rodzinne i instytucjonalne formy opieki (pp. 216-217). Warszawa: Wydawnictwa Szkolnei Pedagogiczne.

Stojecka-Zuber, R. (2009). Usamodzielnia nie wychowanków placówek socjalizacyjnych założenia a rzeczywistość. In R. Stojecka-Zuber, \& A. Róg (Eds.). System opiekiipomocy. Założenia a rzeczywistość (pp. 477, 482, 487). Tarnobrzeg: Wydawnictwo Państwowej Wyższej Szkoły Zawodowejim. prof. Stanisława Tarnowskiego.

Węgierski, Z. (2006). Opieka nad dzieckiem osieroconym. Teoria i praktyka (pp. 45, 50). Toruń: Wydawnictwo Edukacyjne "AKAPIT". 


\section{Kelias nuo nepalankios šeimos iki savos šeimos: socialinių našlaičių patirtys ir lūkesčiai}

Anita Mencel

Vroclavo universitetas, Istorijos ir pedagogikos katedra, Pedagogikos institutas,

J. W. Dawida g. 1, 50-527 Vroclavas, Lenkija, mencel.a@wp.pl

\section{Santrauka}

Šių dienų pasaulyje šeima išlieka aukščiausia vertybè, bet tuo pačiu ji patiria ir ịvairių destabilizuojančių veiksnių itaką - tai gali jai trukdyti tinkamai funkcionuoti. Tokioje šeimos aplinkoje, kur stipriai pasireiškia neigiamų veiksnių ịtaka, augančių vaikų gyvenimas yra problemiškas ir tai, savo ruožtu, veda prie socialinès našlaitystės situacijos, t. y. susiduriame su reiškiniu, kai šeimoje neprižiūrimas vaikas yra paimamas iš šeimos ì globos namus. Tokie vaikai patiria specifinę socializaciją, kurią charakterizuoja institucijos ir kilmès šeimos sąlygų neatitikimas, o visi tapsmo savarankišku žmogumi procesai šeimos, kasdienio gyvenimo, mokyklos, profesinio ir socialinio gyvenimo srityse atspindi ši neatitikimą. Visos šios vaiko gyvenimo sritys yra glaudžiai persipynusios ir sudaro jauno žmogaus savarankiško funkcionavimo suaugus veiksnių visumą. Šių veiksnių sudètingumą ir svarbą tampant suaugusiuoju atspindi respondentų asmeniniai išgyvenimai, išsakyti interviu metu.

Esminiai žodžiai: ribinè socializacija, nepalanki šeima, socialinè našlaitystè, institucinis ugdymas, tapsmo savarankišku žmogumi procesas globos namu aplinkoje.

Itteikta / Received 2013-12-05

Priimta / Accepted 2014-10-12 